Marquette University

e-Publications@Marquette

$1-1-2001$

"Many Lamps Are Lightened From the One":

Paradigms of the Transformational Vision in Macarian Homilies

Andrei Orlov

Marquette University, andrei.orlov@marquette.edu

Accepted version. Vigiliae Christianae, Vol. 55, No. 3, (2001): 281-298. DOI: (c) 2001 Brill. Used with permission. 


\title{
"Many Lamps are Lightened from the One": Paradigms of the Transformational Vision in the Macarian Homilies
}

\author{
Andrei A. Orlov \\ Theology Department, Marquette University \\ Milwaukee, WI
}

Among mystical testimonies circulating in the Eastern Christian tradition, two portentous descriptions of transformational visions can be found.

The first account is drawn from 2 Enoch, a Jewish apocalypse, apparently written in the first century CE and preserved in the Eastern Christian environment in its Slavonic translation. In this text the prediluvian patriarch Enoch describes his luminous metamorphosis near the Throne of Glory:

And Michael, the Lord's greatest archangel, lifted me up and brought me in front of the face of the Lord ... And Michael extracted me from my clothes. He anointed me with the delightful oil; and the appearance of that oil is greater than the greatest light, its ointment is like sweet dew, and its fragrance like myrrh; and its shining is like the sun. And I gazed at all of myself, and I had become like one of the glorious ones, and there was no observable difference. ${ }^{1}$

The second account is written a thousand years later and comes from Philokalia, a collection of Eastern Christian writings compiled by 
NOT THE PUBLISHED VERSION; this is the author's final, peer-reviewed manuscript. The published version may be accessed by following the link in the citation at the bottom of the page.

Nicodemus Hagioretes, in which Pseudo-Symeon conveys preparatory instructions for acquiring the vision of the Taboric light:

Then sit down in a quite cell, in a corner by yourself, and do what I tell you. Close the door, and withdraw your intellect from everything worthless and transient. Rest your beard on your chest, and focus your physical gaze, together with the whole of your intellect, upon the centre of your belly or your navel. Restrain the drawing-in of breath through your nostrils, so as not to breathe easily, and search inside yourself with your intellect so as to find the place of the heart, where all the powers of the soul reside. To start with, you will find there darkness and an impenetrable density. Later, when you persist and practice this task day and night, you will find, as though miraculously, an unceasing joy. For as soon as the intellect attains the place of the heart, at once it sees things of which it previously knew nothing. It sees the open space within the heart and it beholds itself entirely luminous and full of discrimination. ${ }^{2}$

It is apparent that these two descriptions belong to very different symbolic worlds. In the first one, an adept, on his celestial trip, finds himself before the glorious appearance of the Lord, accompanied by the angels who extract the visitor from his earthly garments and anoint him with delightful oil. In the second one, he is led through darkness and "an impenetrable density" on the inner journey to the depth of his heart. The majesty of the celestial environment strikingly confronts the monotonous quietness of the inner contemplation. Still, something similar is recognizable in these two accounts. In both descriptions the visionaries eventually come to the same result - they behold themselves luminescent. Both accounts also stress the totality of this metamorphosis - mystical adepts of these visions become "entirely" luminous. It is, however, observable that in the two accounts the source of the divine light is different. In the first account, it comes from outside, namely from the glorious appearance of the Lord, depicted symbolically as the angelic anointing with shining oil. The shining oil, the "covering" substance of the transformation, serves as an additional detail which stresses the outer nature of the visionary's luminous metamorphosis.

The important feature of the second account which differentiates it from the first is the "inner" nature of the luminous metamorphosisthe illumination comes from inside, from the darkness of the soul, proceeding from the open space within the heart of the visionary.

Vigiliae Christianae, Vol. 55 (2001): pg. 281-298. DOI. This article is @ Brill Academic Publishers and permission has been granted for this version to appear in e-Publications@Marquette. Brill Academic Publishers does not grant permission for this article to be further copied/distributed or hosted elsewhere without the express permission from Brill Academic Publishers. 
NOT THE PUBLISHED VERSION; this is the author's final, peer-reviewed manuscript. The published version may be accessed by following the link in the citation at the bottom of the page.

Separated by a millennium, these two accounts serve as significant markers of the long-lasting theological journey from the outer transformational vision to its inner counterpart. On this journey the towering figure of the Syrian father, known to us as PseudoMacarius, remains prominent. The purpose of this article is to explore some of his concepts which in our opinion play a formative role in the transition from outer to inner in the transformational visions of Eastern Christian tradition.

\section{The Background: Transformational Vision of the Kavod}

In order to clarify the differences between the two transformational visions mentioned earlier, we must return now to the initial theological contexts which lie behind these two accounts.

The origin of the Kavod paradigm, which is formative for the vision in the Slavonic apocalypse, can be traced to Old Testament materials where one can find various polemics for and against the anthropomorphic understanding of God. ${ }^{3}$ Weinfeld observes that the imagery of the enthroned divine glory known to us as the Lord's Kavod was "crystallized" in the Priestly and Ezekielian traditions. ${ }^{4}$

Theological developments of the Priestly tradition demonstrate that the anthropomorphism of the Priestly source is intimately connected with the place of Divine habitation. ${ }^{5}$ In this tradition, "in which the Divinity is personalized and depicted in the most tangible corporeal similitudes," God, who possesses a human form, has a need for a house or tabernacle. ${ }^{6}$

Weinfeld rightly observes that this anthropomorphic position was not entirely an invention of the Priestly source ${ }^{7}$ but derived from early sacral conceptions. ${ }^{8}$ In these traditions the Deity was sitting in his house ensconced between the two cherubim, and at his feet rests the ark, ${ }^{9}$ his footstool. ${ }^{10}$

This motif of the enthroned Deity becomes a central image in the book of Ezekiel, whose Kavod ${ }^{11}$ theology is similar ${ }^{12}$ to the Priestly doctrine. ${ }^{13}$ Mettinger observes that "in Ezekiel, the Kavod-conception

Vigiliae Christianae, Vol. 55 (2001): pg. 281-298. DOI. This article is @ Brill Academic Publishers and permission has been granted for this version to appear in e-Publications@Marquette. Brill Academic Publishers does not grant permission for this article to be further copied/distributed or hosted elsewhere without the express permission from Brill Academic Publishers. 
proved to represent an earlier phase than that discovered in the Pmaterials." ${ }^{14} \mathrm{He}$ further stresses that the iconography of Ezekiel is closely connected with the idea of God's royal presence in his sanctuary. ${ }^{15}$ This connection of the Kevod YHWH with the enthroned God can scarcely be divorced from its previously established usage in early royal contexts. ${ }^{16}$

Weinfeld notes that Ezekiel's persistent tendency to describe God's Kavod as a brilliant and radiant fire encased in a cloud is also a distinct characteristic of the Priestly writings. ${ }^{17}$ He argues that in the Priestly and Ezekielian writings the fire and cloud are inseparable elements of the apparition of God's Glory, where the cloud is the divine envelope which screens the Deity from mortal view. ${ }^{18}$ In later Jewish and Christian traditions the radiant luminosity emitted by various celestial beings fulfills the same function, protecting against the direct vision of their true forms. In the Hebrew Bible, as well as in later apocalyptic traditions, God's "form" remains hidden behind His light. The hidden Kavod is revealed through its light. ${ }^{19}$ This situation explains the wide use of the Kavod paradigm in the visions of light phenomena.

Kavod theology leads to the special type of transformational visions that can be found in various biblical and apocalyptic materials. ${ }^{20}$ In the climactic points of these accounts, their visionaries normally "see" the extent of the divine glory, often portrayed as enthroned anthropomorphic figure. As a consequence of this encounter, the visionary experiences a dramatic external metamorphosis which often affects his face, limbs, and garments, making them luminescent. A classic example of such a transformational vision is the account of Moses' shining countenance in Ex 34 after his encounter with the Lord's Kavod on Mount Sinai. It is noteworthy that in the apocalyptic and Merkabah traditions the vision of the Lord's Glory ("the King in His beauty") increasingly become the main teleological point of the heavenly ascents.

Enoch's transformation in the Slavonic apocalypse also belongs to the Kavod paradigm. Enoch's luminous metamorphosis took place in the front of the Lord's glorious "extent," labeled in 2 Enoch as the Lord's "Face."21 From this Enochic account we learn that the vision of the Divine "Face" had dramatic consequences for Enoch's appearance.

Vigiliae Christianae, Vol. 55 (2001): pg. 281-298. DOI. This article is @ Brill Academic Publishers and permission has been granted for this version to appear in e-Publications@Marquette. Brill Academic Publishers does not grant permission for this article to be further copied/distributed or hosted elsewhere without the express permission from Brill Academic Publishers. 
His body endures radical changes as it becomes covered with the divine light. A significant detail in this description is that Enoch is not transformed into light but covered, "clothed," with the light of God's Glory. The use of delightful oil as a covering substance emphasizes this "covering nature" of the luminous metamorphosis.

In Enoch's radiant metamorphosis before the Divine Face an important detail can be found which links Enoch's transformation with that of Moses' account in Exodus. In 2 Enoch 37 we learn about the unusual procedure performed on Enoch's face in the final stage of his encounter with the Lord. The text informs that the Lord called one of his senior angels to chill the face of Enoch. The text says that the angel appeared frigid; he was as white as snow, and his hands were as cold as ice. The text further depicts the angel chilling Enoch's face, who could not endure the terror of the Lord, "just as it is not possible to endure the fire of a stove and the heat of the sun...."22 Right after this "chilling procedure," the Lord informs Enoch that if his face had not been chilled here, no human being would have been able to look at his face. ${ }^{23}$ This reference to the radiance of Enoch's face after his encounter with the Lord is an apparent parallel to the incandescent face of Moses after the Sinai experience in Ex 34.

In spite of the dominant role of the Kavod pattern in biblical and apocalyptic theophanic accounts, it becomes increasingly challenged in the postbiblical rabbinic ${ }^{24}$ and patristic environments which offered new understandings of the transformational vision. In these new developments, one can see a growing emphasis on the interiorization of the visionary experience. ${ }^{25}$ Among the new notions employed for the purposes of such a paradigm shift was the prominent biblical concept of the image of God after which Adam was created.

\section{In the Likeness of God's Image}

In his book Makarius, Das Thomasevangelium und das Lied von der Perle ${ }^{26}$ Gilles Quispel draws the reader's attention to an interesting tradition preserved in Homily II.12 $2^{27}$ of Pseudo-Macarius. From the homily we learn that "Adam, when he transgressed the commandment, lost two things. First, he lost the pure possession of his nature, so lovely, created according to the image and likeness of

Vigiliae Christianae, Vol. 55 (2001): pg. 281-298. DOI. This article is @ Brill Academic Publishers and permission has been granted for this version to appear in e-Publications@Marquette. Brill Academic Publishers does not grant permission for this article to be further copied/distributed or hosted elsewhere without the express permission from Brill Academic Publishers. 
NOT THE PUBLISHED VERSION; this is the author's final, peer-reviewed manuscript. The published version may be accessed by following the link in the citation at the bottom of the page.

God (kat' ei) ko\&na kai_o (moi\&wsin tou= Qeou=). Second, he lost the very image itself ( $a u)$ th_n ei) ko\&na) in which was laid up for him, according to God's promise, the full heavenly inheritance"(II.12.1).28 Further, another important passage in the homily informs the reader that Adam and Eve before the Fall were clothed (e) ndedume\&noi) with God's glory in place of clothing (peribolai\&ou) (II.12.8).29 The text reveals a certain continuity between Adam's "very image itself" and his glorious clothing. An important detail in the narrative is that the homilist makes a distinction between Adam's nature, created according to the image and likeness of God ${ }^{30}$ and Adam's "very image (ei) ko\&na) itself," speaking about them as of two separate entities which were lost during the Fall. This subtle theological distinction shows the author's familiarity with the Jewish aggadic traditions about tselem (Heb. Mlc) of Adam-the luminous image of God's glory according to which Adam was created. ${ }^{31}$

The term "image" (Gk. ei) kw\&n) can be found in a number of significant New Testament passages. The most important of them for the purposes of the current investigation is the Pauline description of Christ as the "image of the invisible God" in Col 1:15, which has often been compared to the account of the creation of Adam and seen as part of Paul's Adam Christology. ${ }^{32}$ This theological connection between Adam's creation after the image of God and Christ as the image of God has opened several possibilities for using ancient aggadic traditions about the luminous tselem of Adam in new Christian theophanic contexts. In Pauline writings we can also see peculiar terminological parallels in which the notion of image (ei) kw\&n) becomes closely associated with important theophanic concepts, prominent in traditional Kavod theology, such as glory ${ }^{33}$ (do\&ca) ${ }^{34}$ and form (morfh\&). ${ }^{35}$

Other important theological developments in Gnostic ${ }^{36}$ and rabbinic circles lead to a gradual "interiorization" of the tselem imagery. In postbiblical Jewish accounts, tselem is often identified with the luminous "clothing" of the human heart. Scholem's research shows that in Jewish mysticism tselem was also understood as a sort of "garment" of the soul, which "floats" over it. He observes that "this garment also becomes the soul's heavenly attire when it returns to

Vigiliae Christianae, Vol. 55 (2001): pg. 281-298. DOI. This article is @ Brill Academic Publishers and permission has been granted for this version to appear in e-Publications@Marquette. Brill Academic Publishers does not grant permission for this article to be further copied/distributed or hosted elsewhere without the express permission from Brill Academic Publishers. 
Paradise after death." 37 This Jewish idea of the "inner" luminous tselem might well be already known in Christian circles, particularly in the Syriac environment.

It is also possible that Ephraem, Macarius, and some other Syrian Christian writers might have acquired the notion of the luminous human tselem through their familiarity with the Targums, the Aramaic renderings of the Hebrew Bible, which attest to traditions about the original luminosity of Adam and Eve. ${ }^{38}$

It is noticeable that in the Macarian homilies and other Eastern Christian writings the notion of luminous tselem became gradually employed for the purposes of the internalized beatific vision. Tselem became utilized as a sort of theological counterpart to the classic concept of the divine Kavod which traditionally played a prominent role in biblical and apocalyptic visions. Sometimes both imageries were used interchangeably.

In the patristic environment the concept of the image of God gradually became a "safer" way to convey visionary experiences of the light phenomena, especially after the anthropomorphite controversy of $399 \mathrm{CE}^{39}$ when antianthropomorpic polemics ${ }^{40}$ made it increasingly difficult to employ the traditional "anthropomorphic" language of beatific visions, including the classical Kavod imagery. ${ }^{41}$ By the fourth century in patristic trinitarian debates about the divine light the Kavod terminology was almost completely substituted by the symbolism of the divine image.

A thousand years later, in Hesychast transformational visions of the Taboric light, the concept of the image of God still continued to play a crucial theological role. It is especially noticeable in Gregory Palamas' theology of the divine image which shows amazing parallels to the concepts and imagery of Macarius. Among them is an open employment of the Adamic Gestalt. Palamas, following Macarius, draws heavily on ancient traditions about the luminous tselem of Adam. In One Hundred and Fifty Texts, he argues that "Adam, before the fall, also participated in this divine illumination and resplendence, and because he was truly clothed in a garment of glory he was not naked, nor was he unseemly by reason of his nakedness." 42 The Syrian background of Palamas' speculation about Adam is evident. ${ }^{43}$ 
Recognizing the tragic consequences which Adam's fall had for the condition of the human tselem, ${ }^{44}$ he reaffirms its irrevocable value for the inner transformational vision: "Leaving aside other matters for the present, I shall simply say that perfection of the divine likeness is accomplished by means of the divine illumination that issues from God."45

The theme of regaining this lost luminous image of God, "the dimmer reflection," which is still mysteriously extant in the human physical body (sometimes in the form of a luminous "clothing" of the heart) and can be eventually "restored," had a number of interesting theological ramifications in the Hesychast tradition. ${ }^{46}$ The Hesychast idea of the light-like ( $f$ wtoeide\&v) sensitive nature of man ${ }^{47}$ shows clear similarities with this early Syrian understanding of the luminous tselem as a reflection of God's Glory.

\section{Internalization of the Kavod}

It was mentioned earlier that in some biblical accounts the figure of Moses is often connected with Kavod theology. ${ }^{48}$ This tendency is traceable both in the Old Testament Exodus stories and in New Testament accounts of Christ's Transfiguration where Moses serves as a significant "theophanic" reminder. In postbiblical Jewish and Christian writings the Moses Gestalt, however, gradually became utilized for the purposes of internalized visions. It cannot be a coincidence that in these new theological "developments," the Moses account was also linked with the tselem imagery.

These tendencies are noticeable in the Macarian Homilies where Moses is often portrayed as Adam's luminous counterpart. Following the already mentioned Adamic narrative of Homily II.12, which tells us how Adam lost his luminous status and "obeyed his darker side," Macarius gives us Moses' example who "had a glory shining on his countenance." The homily refers to Moses' Sinai experience, expanding this tradition and adding some new significant details:

Indeed, the Word of God was his food and he had a glory shining on his countenance. All this, which happened to him, was a figure of something else. For that glory now shines splendidly from within the hearts of Christians. At the resurrection their bodies, as they rise, will be covered (skepa\&zetai) with

Vigiliae Christianae, Vol. 55 (2001): pg. 281-298. DOI. This article is @ Brill Academic Publishers and permission has been granted for this version to appear in e-Publications@Marquette. Brill Academic Publishers does not grant permission for this article to be further copied/distributed or hosted elsewhere without the express permission from Brill Academic Publishers. 
another vesture, one that is divine, and they will be nourished with a heavenly food (II.12.14). ${ }^{49}$

It is noticeable that the passage serves as a bridge between the symbolic worlds of the Kavod and tselem. Macarius openly "internalizes" the Moses account, stressing that Moses' glory now "shines splendidly from within the hearts of Christians." On the other hand, some features of the Kavod's paradigm are still noticeable: the homilist understands Moses' luminosity as a covering with God's glory. ${ }^{50}$ The author's further discussion in II.12.15 about the clothing of Christians and wrapping them in "divine and glorious garments" gives additional strength to this motif of Moses, covered with the luminous garments of God's glory.

The tendencies for internalizing the Kavod paradigm through implications of the concept of God's image found in Macarian Homilies demonstrate amazing similarities to some Jewish developments. The late Rabbinic midrashim attest to such traditions. ${ }^{51}$ The origin of such theological innovations can be found in its rudimentary form already in some Jewish apocalypses, notably in 2 Enoch from which we learn that the Lord created Adam after His Face. F. Andersen stresses the theological uniqueness of such creational imagery. He, however, does not clarify what the creation after the Lord's Face means in the broader textual context of the Slavonic apocalypse. The Lord's Face plays an important role in 2 Enoch's theophanic descriptions being identified with the Lord's glorious form-His Kavod. In chapter 22 of 2 Enoch the Lord's Face emits light and fire and serves as the source of Enoch's luminous metamorphosis. In this context, the creation of Adam after the Lord's Face demonstrates a remarkable effort toward merging the Kavod and tselem paradigms of the transformational vision.

The previous investigation shows the important role of the Adam-Moses connection in the evolution from outer to inner in Kavod imagery. It is clear, however, that in the Macarian writings the internalizing of the Kavod paradigm is not confined solely to the reevaluation of Moses' Gestalt. The effort is much more radical. In fact, it is so revolutionary that it strikes even distinguished students of the mystical traditions. One of them, Gershom Scholem, points to the amazing Macarian tendency for mystical "reinterpretation" of the

Vigiliae Christianae, Vol. 55 (2001): pg. 281-298. DOI. This article is @ Brill Academic Publishers and permission has been granted for this version to appear in e-Publications@Marquette. Brill Academic Publishers does not grant permission for this article to be further copied/distributed or hosted elsewhere without the express permission from Brill Academic Publishers. 
NOT THE PUBLISHED VERSION; this is the author's final, peer-reviewed manuscript. The published version may be accessed by following the link in the citation at the bottom of the page.

Merkabah vision of Ezekiel in which the human soul become itself the throne of glory. ${ }^{52}$ In Homily II.1.1-2 Macarius writes:

When Ezekiel the prophet beheld the divinely glorious vision, he described it in human terms but in a way full of mysteries that completely surpass the powers of the human mind.... And all of this which the prophet saw in ecstasy or in a trance was indeed true and certain, but it was only signifying and foreshadowing something no less hidden, something divine and mysterious, "a mystery hidden for generations" (Col 1:26) but that "has been revealed only in our time, the end of the ages," (1 Pt 1:20) when Christ appeared. For the prophet was viewing the mystery of the human soul that would receive its Lord and would become his throne of glory. For the soul that is deemed to be judged worthy to participate in the light of the Holy Spirit by becoming his throne and habitation, and is covered with the beauty of ineffable glory of the Spirit, becomes all light, all face, all eye. ${ }^{53}$

Scholem, observing such a radical rethinking of classic Kavod imagery, further asks the legitimate question: "was there not a temptation to regard man himself as the representative of divinity, his soul as the throne of glory?"54 Interestingly enough, this query directs us to the very heart of the Macarian theological enterprise in which the Kavod internalization become possible only as a consequence of the unique interrelationships between human and divine in the event of Christ's transfiguration.

\section{Crystallization of the New Paradigm: The Macarian Account of the Lord's Transfiguration}

The previous analysis shows that in the Macarian homilies Moses' shining countenance and the luminosity of Adam's prelapsarian tselem serve as metaphors for major paradigms of the transformational vision.

In the Macarian writings, one can also encounter a third paradigm of luminous transformation which is radically different from the previous two traditions. In a peculiar Macarian understanding of Christ's transfiguration ${ }^{55}$ on Mt. Tabor, the duality of inner and outer in the visio Dei is expressed in a new metaphor of the transformational vision-Christ's "Body56 of Light." 57

Vigiliae Christianae, Vol. 55 (2001): pg. 281-298. DOI. This article is @ Brill Academic Publishers and permission has been granted for this version to appear in e-Publications@Marquette. Brill Academic Publishers does not grant permission for this article to be further copied/distributed or hosted elsewhere without the express permission from Brill Academic Publishers. 
NOT THE PUBLISHED VERSION; this is the author's final, peer-reviewed manuscript. The published version may be accessed by following the link in the citation at the bottom of the page.

Macarius makes an important theological statement when he observes that in His Transfiguration Christ was not just covered by the Glory but "was transfigured into (metemorfw\&qh ei) j) divine glory and into infinite light (ei) $v$ to_ $f \mathrm{w}=\mathrm{v}$ to_ a!peiron)" (II.15.38). ${ }^{58}$

In II.15.38 the homilist elaborates this ingenious understanding of Christ's transfiguration in which the internal and external aspects of transformational mystical experience are absolutely resolved:

For as the body of the Lord was glorified when he climbed the mount and was transfigured into the divine glory and into infinite light, so also the bodies of the saints are glorified and shine like lightning. ${ }^{59}$ Just as the interior glory of Christ covered his body and shone completely, in the same way also in the saints the interior power of Christ in them in the day will be poured out exteriorly upon their bodies... (II.15.38). ${ }^{60}$

The language of the passage further reinforces the totality of this transformational vision-Christ's internal glory serves as the teleological source of his complete, luminous metamorphosis.

In the articulation of the newness of Christ's condition, Macarius thus offers a completely new paradigm of the beatific vision-the bodies of visionaries are now not simply covered externally with the divine light but are "lightened"61 in the way as many lamps are lightened from the one:

Similarly, as many lamps are lighted from the one, same fire, so also it is necessary that the bodies of the saints, which are members of Christ, become the same which Christ himself is. (II.15.38). ${ }^{62}$

In this new concept of the transformational vision, Macarius, however, sets a significant distinction between Christ's Transfiguration and human luminous transformation. In contrast to the Lord's metamorphosis, the bodies of mortals cannot be completely "transfigured into the divine glory" but rather simply become "glorified."

The hypostatic quality of Christ's luminous form is what differentiates Him from transformed Christians who are only predestined to participate in the light of His Glory and "have put on the raiment of ineffable light." 63 This articulation of the distinction between

Vigiliae Christianae, Vol. 55 (2001): pg. 281-298. DOI. This article is @ Brill Academic Publishers and permission has been granted for this version to appear in e-Publications@Marquette. Brill Academic Publishers does not grant permission for this article to be further copied/distributed or hosted elsewhere without the express permission from Brill Academic Publishers. 
NOT THE PUBLISHED VERSION; this is the author's final, peer-reviewed manuscript. The published version may be accessed by following the link in the citation at the bottom of the page.

Christ's hypostasis and His light will play later an important role in Palamas' dialectics of God's essence and the divine energies.

\section{Conclusion}

It is time to return to the passage from the Philokalia which began this investigation. In comparison with the "traditional" cases of transformational visions, this account might appear as quite ambiguous. It demonstrates the absence of significant details of such visions in which the luminous metamorphosis of a visionary becomes possible as the consequence of the beatific vision of the glorious "form" of the Deity. The teleological necessity of such a divine form, in its external or internal manifestations, seems to presuppose the very possibility of any luminous metamorphosis. On the contrary, in the Philokalia account a visionary does not see any luminous form, but "the open space within the heart," which, however, makes him entirely luminous.

The answer to this strange situation can be found in the Macarian understanding of Christ's transfiguration on Mount Tabor which plays a paradigmatic role in later Hesychastic visions of the divine light. Macarius' position implies that Christ in the Tabor story represents both aspects of the transformational vision. First, He is the Glory after which a visionary is transformed. Second, He is also the visionary himself, whose face and garments are transformed.64 In the Macarian writings Christ's interior glory is poured out upon his external body, making it luminous.

For as the body of the Lord was glorified when he climbed the mount and was transfigured into the divine glory and into infinite light, so also the bodies of the saints are glorified and shine like lightning. Just as the interior glory of Christ covered his body and shone completely, in the same way also in the saints the interior power of Christ in them in the day will be poured out exteriorly upon their bodies.... (II.15.38). ${ }^{65}$

In the light of the Macarian account of Christ's transfiguration, the requirement for the divine glorious form as the transforming source of the visionary experience becomes replaced by the notion of the divine energies. It becomes possible since the locus of the visionary's perspective now is not external to the divine luminous form, but is rather immanent within it. In this situation the dichotomy between the 
subject of the beautific vision and the object of the beautific vision can be easily overcome.

A Hesychast in his transformational vision intends to resemble Christ in the Transfiguration. He focuses his physical and intellectual gaze not on the outside but on the inside, upon his heart, "where all the powers of the soul reside," waiting patiently that the interior power of Christ will lighten him as a lamp, so he can "become the same which Christ himself is." Divine glory here, just as in the Kavod tradition, is still confined within the anthropomorphic form, but there is a substantial difference-this human form is now the visionary himself, who imitates Christ's transfiguration, whose inner glory pours out exteriorly upon the body.

\section{Notes}

12 Enoch 22:6-10. F. I. Andersen, "2 (Slavonic Apocalypse of) Enoch," The Old Testament Pseudepigrapha (2 vols.; ed. J. H. Charlesworth; New York: Doubleday, 1985 [1983]), 1.139.

2 Pseudo-Simeon, "The Three Methods of Prayer," in: The Philokalia (5 vols.; tr. G. E. H. Palmer, P. Sherrard, and K. Ware; London: Faber and Faber, 1995), 4.72-3.

3 On the issue of Old Testament's anthropomorphism see: J. Barr, "Theophany and Anthropomorphism in the Old Testament," VT Suppl. 7 (1960) 31-8; J. Hempel, "Die Grenzen des Anthropomorphismus Jahwes im Alten Testament," ZAW 57 (1939) 75-85; F. Michaeli, Dieu à l'image de l'homme: Étude de la notion anthropomorphique de Dieu dans I'Ancient Testament (Neuchâtel: Delachaux, 1950); W. Eichrodt, Theology of the Old Testament (2 vols.; Philadelphia: The Westminster Press, 1961), 1.210-20; M. C. A. Korpel, A Rift in the Clouds. Ugaritic and Hebrew Descriptions of the Divine (UBL, 8; Münster: UGARITVerlag, 1990), 87-590; T. N. D. Mettinger, The Dethronement of Sabaoth. Studies in the Shem and Kabod Theologies (Coniectanea Biblica. Old Testament Series, 18; Lund: Wallin \& Dalholm, 1982); M. Weinfeld, Deuteronomy and the Deuteronomic School (Oxford: Clarendon Press, 1972), 191-209. On later Jewish anthropomorphism see: M. Fishbane, "The 'Measures' of God's Glory in the Ancient Midrash," in I. Gruenwald et al. (eds.), Messiah and Christos: Studies in the Jewish Origins of Christianity. Presented to David Flusser on the Occasion of His Seventy-Fifth Birthday (Tübingen: Mohr/Siebeck,

Vigiliae Christianae, Vol. 55 (2001): pg. 281-298. DOI. This article is @ Brill Academic Publishers and permission has been granted for this version to appear in e-Publications@Marquette. Brill Academic Publishers does not grant permission for this article to be further copied/distributed or hosted elsewhere without the express permission from Brill Academic Publishers. 
1992), 53-74; Arthur Marmorstein, The Old Rabbinic Doctrine of God: Essays in Anthropomorphism (New York: KTAV, 1937).

${ }^{4} \mathrm{M}$. Weinfeld, Deuteronomy and the Deuteronomic School (Oxford: Clarendon, 1972), 191.

${ }^{5}$ T. N. D. Mettinger, The Dethronement of Sabaoth. Studies in the Shem and Kabod Theologies (Coniectanea Biblica. Old Testament Series, 18; Lund: Wallin \& Dalholm, 1982), 24.

${ }^{6}$ Weinfeld, Deuteronomy and the Deuteronomic School, 191.

${ }^{7}$ For the roots of the theology of the priestly tabernacle see: Mettinger, The Dethronement of Sabaoth. Studies in the Shem and Kabod Theologies, 81-3.

${ }^{8}$ Weinfeld shows that "the notion of God sitting enthroned upon the cherubim was prevalent in ancient Israel (1 Sam 4:4; 2 Sam 6:2; Ps 80:2; 2 Kgs 19:15)." Weinfeld, Deuteronomy and the Deuteronomic School, 192.

${ }_{9}^{9}$ Mettinger stresses that "the most important aspect of the Ark in Solomon's Temple was that it served as the footstool of God." Mettinger, The Dethronement of Sabaoth. Studies in the Shem and Kabod Theologies, 87.

${ }^{10}$ M. Haran, "The Ark and the Cherubim," IEJ 9 (1959) 30-8.

${ }^{11}$ The term Kavod (Heb. dwbk) occurs 199 times in the Old Testament (24 occurences in the Pentateuch, 7 in the Deuteronomistic history, 18 in the Chronicler's history, 38 in Isaiah, 19 in Ezekiel, occasionaly in Jeremiah and the Minor Prophets, 51 occurences in the Psalms and 16 in Proverbs). The term dwbk can be translated as "substance," "body," "mass," "power," "might," "honor," "glory," "splendor." In its meaning as "glory" Kavod usually refers to God, his sanctuary, his city, or sacred paraphernalia. The Priestly tradition uses the term in connection with God's appearences in the tabernacle. P and Ezekiel describe Kavod as a blazing fire surrounded by radiance and a great cloud. M. Weinfeld, "dwbk," TDOT, 7.22-38.

${ }^{12}$ It is also noteworthy that Ezekiel and the materials of the Priestly tradition, such as Gen 5:1, share similar terminology, namely the term twmd. The term twmd appears 12 times in the Book of Ezekiel where it becomes a favorite terminology for the description of various divine and angelic "appearances." It occupies a prominent place in Biblical anthropomorphic debates. Both terms dwbk and twmd are intimately connected through the notion of "hiddeness" of the Divine form/glory. Later Jewish Shciur Qomah traditions stress the aspect of the granted for this version to appear in e-Publications@Marquette. Brill Academic Publishers does not grant permission for this article to be further copied/distributed or hosted elsewhere without the express permission from Brill Academic Publishers. 
hiddeness of twmd: "His twmd is hidden from everyone, but no one's twmd is hidden from Him." M. S. Cohen, The Shicur Qomah: Liturgy and Theurgy in Pre-Kabbalistic Jewish Mysticism (Lanham: University Press of America, 1983), 113. For a fuller discussion see A. De Conick, Seek to See Him: Ascent and Vision Mysticism in the Gospel of Thomas (SVC, 33; Leiden: Brill, 1996), 102-4.

13 On the connections between $\mathrm{P}$ and Ezekiel see B. Stein, Der Begriff "Kebod Jahweh" (Emsdetten; Lechte, 1939), 299. See also Mettinger, The Dethronement of Sabaoth. Studies in the Shem and Kabod Theologies, 107-11.

14 Mettinger, The Dethronement of Sabaoth. Studies in the Shem and Kabod Theologies, 116-17.

15 Mettinger, The Dethronement of Sabaoth. Studies in the Shem and Kabod Theologies, 117.

16 Mettinger, The Dethronement of Sabaoth. Studies in the Shem and Kabod Theologies, 117.

17 Weinfeld, Deuteronomy and the Deuteronomic School, 201.

18 Weinfeld, Deuteronomy and the Deuteronomic School, 202.

19 De Conick, Seek to See Him, 104-5. De Conick's research investigates the relationships between God's form and God's light, showing their complexity. She argues that in some traditions God's form remains hidden behind His light. The hidden Kavod is revealed through its light. "The visionary can only gain access to a vision of the deity through the deity's light." De Conick, Seek to See Him, 104-5. ${ }^{20}$ G. Quispel, "Ezekiel 1:26 in Jewish Mysticism and Gnosis," VC 34 (1980) $1-13$.

21 "I saw the view of the face of the Lord, like iron made burning hot in a fire and brought out, and it emits sparks and is incandescent. Thus even I saw the face of the Lord. But the face of the Lord is not to be talked about, it is so very marvelous and supremely awesome and supremely frightening. And who am I to give an account of the incomprehensible being of the Lord, and of his face, so extremely strange and indescribable? And how many are his commands, and his multiple voice, and the Lord's throne, supremely great and not made by hands, and the choir stalls all around him, the cherubim and the seraphim armies, and their never-silent singing. Who can give an account of his beautiful appearance, never changing and indescribable, and his great glory? And I fell down flat and did obeisance to the Lord" (2 Enoch 22:1-4, the longer recension). Andersen, 136. granted for this version to appear in e-Publications@Marquette. Brill Academic Publishers does not grant permission for this article to be further copied/distributed or hosted elsewhere without the express permission from Brill Academic Publishers. 
19 De Conick, Seek to See Him, 104-5. De Conick's research investigates the relationships between God's form and God's light, showing their complexity. She argues that in some traditions God's form remains hidden behind His light. The hidden Kavod is revealed through its light. "The visionary can only gain access to a vision of the deity through the deity's light." De Conick, Seek to See Him, 104-5. ${ }^{20}$ G. Quispel, "Ezekiel 1:26 in Jewish Mysticism and Gnosis," VC 34 (1980) 1-13.

21 "I saw the view of the face of the Lord, like iron made burning hot in a fire and brought out, and it emits sparks and is incandescent. Thus even I saw the face of the Lord. But the face of the Lord is not to be talked about, it is so very marvelous and supremely awesome and supremely frightening. And who am I to give an account of the incomprehensible being of the Lord, and of his face, so extremely strange and indescribable? And how many are his commands, and his multiple voice, and the Lord's throne, supremely great and not made by hands, and the choir stalls all around him, the cherubim and the seraphim armies, and their never-silent singing. Who can give an account of his beautiful appearance, never changing and indescribable, and his great glory? And I fell down flat and did obeisance to the Lord" (2 Enoch 22:1-4, the longer recension). Andersen, 136.

22 Andersen, 160.

23 Andersen, 160.

${ }^{24}$ It becomes especially notable in Hekhaloth mysticism, where the teleology of the mystical journeys came to be expressed in terms of descent into the Merkabah. On Merkabah and Hekhaloth mysticism, see: P. Alexander, "The Historical Settings of the Hebrew Book of Enoch," JJS 28 (1977) 156-80; D. Blumenthal, Understanding Jewish Mysticism: A Source Reader (2 vols.; New York: KTAV, 1978); I. Chernus, Mysticism in Rabbinic Judaism (SJ, 11; Berlin/New York: de Gruyter, 1982); M. Cohen, The Shiur Qomah: Liturgy and Theurgy in Pre-Kabbalistic Jewish Mysticism (Lanham: University Press of America, 1983); J. Greenfield, "Prolegomenon," in: H. Odeberg, 3 Enoch or the Hebrew Book of Enoch (New York: KTAV, 1973), xi-xlvii; I. Gruenwald, Apocalyptic and Merkavah Mysticism (AGJU, 14; Leiden: Brill, 1980); Gruenwald, I. and M. Smith, The Hekhaloth Literature in English (Chico, CA: Scholars, 1983); D. Halperin, The Faces of the Chariot: Early Jewish Responses to Ezekiel's Vision (TSAJ, 16; Tübingen: Mohr/Siebeck, 1988); D. Halperin, The Merkavah in granted for this version to appear in e-Publications@Marquette. Brill Academic Publishers does not grant permission for this article to be further copied/distributed or hosted elsewhere without the express permission from Brill Academic Publishers. 
Rabbinic Literature (New Haven: American Oriental Society, 1980); M. Idel, "Enoch is Metatron," Immanuel 24/25 (1990) 220-40; L. Jacobs, Jewish Mystical Testimonies (New York: Schocken Books, 1977); N. Janowitz, The Poetics of Ascent: Theories of Language in a Rabbinic Ascent Text (Albany: State University of New York Press, 1989); M. Morgan, Sepher ha-Razim: The Book of Mysteries (TTPS, 11; Chico, CA: Scholars, 1983); C. Morray-Jones, "Hekhaloth Literature and Talmudic Tradition; Alexander's Three Test Cases," JJS 22 (1991) 139; C. Newsom, Songs of Sabbath Sacrifice: A Critical Edition (HSS, 27; Atlanta: Scholars Press, 1985); A. Orlov, "Titles of Enoch-Metatron in 2 Enoch," JSP 18 (1998) 71-86; P. Schäfer with M. Schlüter and H. G. von Mutius, Synopse zur Hekhalot-Literatur (TSAJ, 2; Tübingen: Mohr/Siebeck, 1981); P. Schäfer, The Hidden and Manifest God (Albany: State University of New York Press, 1992); P. Schäfer et al., Übersetzung der Hekhalot-Literatur (4 vols.; TSAJ, 17, 22, 29, 46; Tübingen: Mohr/Siebeck, 1987-95); G. Scholem, Jewish Gnosticism, Merkabah Mysticism and Talmudic tradition (New York: Jewish Theological Seminary of America, 1965); idem, Major Trends in Jewish Mysticism (New York: Schocken, 1954); N. Séd, "Les traditions secrètes et les disciples de Rabban Yohannan ben Zakkai," RHR 184 (1973) 49-66; M. Swartz, Mystical Prayer in Ancient Judaism: An Analysis of Maaseh Merkavah (TSAJ, 28; Tübingen: Mohr/Siebeck, 1992).

${ }^{25}$ On the issue of the interiorization of transformational visions see: $A$. Golitzin, "Liturgy and Mysticism: The Experience of God in Eastern Orthodox Christianity," Pro Ecclesia 2 (1999) 159-86; Ieromonah Alexander (Golitzin), "Forma lui Dumnezeu şi Vederea Slavei. Reflecţii Asupra Controversei Antropomorfite Din Anul 399 D. Hr.," in: Ieromonah Alexander (Golitzin), Mistagogia. Experienţa lui Dumnezeu în Ortodoxie (Sibiu: Deisis, 1998), 184-267; N. Séd, "La shekinta et ses amis araméens," Cahiers d'Orientalisme 20 (1988) 133-42.

26 G. Quispel, Makarius, Das Thomasevangelium und das Lied von der Perle (SNT, 15; Leiden: Brill, 1967), 57-8.

27 There are four Byzantine medieval collections of Macarian Homilies. Three of them appeared in critical editions. Collection I was published in Makarios/Simeon: Reden und Briefe. Die Sammlung I des Vaticanus Graecus 694 (B) (2 vols.; ed. H. Bertold, GCS; Berlin: AcademieVerlag, 1973). Collection II appeared in: H. Dörries, E. Klostermann, and M. Kroeger Die 50 Geistlichen Homilien des Makarios (PTS, 4;

Vigiliae Christianae, Vol. 55 (2001): pg. 281-298. DOI. This article is @ Brill Academic Publishers and permission has been granted for this version to appear in e-Publications@Marquette. Brill Academic Publishers does not grant permission for this article to be further copied/distributed or hosted elsewhere without the express permission from Brill Academic Publishers. 
Berlin: De Gruyter, 1964). Collection III appeared in Neue Homilien des Makarios/Simeon aus Typus III (eds. E. Klostermann and H. Berthold; TU, 72; Berlin: Akademie-Verlag, 1961) and PseudoMacaire. Oeuvres spirituelles. Vol. I: Homélies propres à la Collection III (ed. V. Desprez; SC, 275; Paris: Cerf, 1980). In our references to the Macarian homilies the first uppercase Roman numeral will designate the Collection, following Arabic numerals will designate the specific homily and its subsections.

28 Pseudo-Macarius, The Fifty Spiritual Homilies and the Great Letter (tr. G. A. Maloney, S.J.; New York: Paulist Press, 1992), 97. H. Dörries et al. Die 50 Geistlichen Homilien des Makarios (PTS, 4; Berlin: De Gruyter, 1964), 107-8.

29 Pseudo-Macarius, The Fifty Spiritual Homilies and the Great Letter, 100.

30 It is important that Genesis 1:26 stresses that Adam's Mlc was created after God's own Mlc, being some sort of luminous "imitation" of the glorious Mlc of God. Some scholars even argue that "in this way, the likeness that Adam and God shared is not physicality-in the normal sense of having a body-but luminescence." David Aaron, "Shedding Light on God's Body," 303.

${ }^{31}$ For discussions about the luminous garment/image/body of Adam see: David H. Aaron, "Shedding Light on God's Body in Rabbinic Midrashim: Reflections on the Theory of a Luminous Adam," HTR 90 (1997) 299-314; S. Brock, "Clothing Metaphors as a Means of Theological Expression in Syriac Tradition," Typus, Symbol, Allegorie bei den östlichen Vätern und ihren Parallelen im Mittelalter (Eichstätter Beiträge, 4; Regensburg: Friedrich Pustet, 1982), 11-40; A. D. De Conick and J. Fossum, "Stripped before God: A New Interpretation of Logion 37 in the Gospel of Thomas," VC 45 (1991) 141; L. Ginzberg, The Legends of the Jews ( 7 vols.; Philadelphia: The Jewish Publication Society of America, 1955), 5.97; Alon Goshen Gottstein, "The Body as Image of God in Rabbinic Literature," HTR 87 (1994) 171-95; B. Murmelstein, "Adam, ein Beitrag zur Messiaslehre," Wiener Zeitschrift für die Kunde des Morgenlandes 35 (1928) 255; W. Staerk, Die Erlösererwartung in den östlichen Religionen (Stuttgart and Berlin, 1938), 11.

32 J. Fossum, The Image of the Invisible God (Novum Testamentum et Orbis Antiquus, 30; Göttingen: Vandenhoeck \& Ruprecht, 1995), 15. Cf. also: A. Schlatter, Die Theologie der Apostel (Stuttgart: Calwer, 
1922), 299; M. Black, "The Pauline Doctrine of the Second Adam," SJT 7 (1954) 174-9; R. Scroggs, The Last Adam (Philadelphia: Fortress, 1966), 97-9.

${ }^{33}$ See for example 2 Cor $4: 4$ : "... the light of the gospel of the glory of Christ, who is the image of God..."

${ }^{34} \mathrm{H}$. A. W. Meyer, J. Weiss and J. Behm understand Paul's concept of morfh\& as the divine Glory (do\&ca), believing that "in Pauline sense, Christ was from the beginning no other than dwbk, do\&ca of God himself, the glory and radiation of his being, which appears almost as an independent hypostasis of God and yet is connected intimately with God." See R.P. Martin, Carmen Christi. Philippians 2.5-11 in Recent Interpretation and in the Setting of Early Christian Worship (Cambridge: Cambridge University Press, 1967), 104-5. One of the major exponents of the hypothesis, J. Behm, in Kittel's TDNT, argues that the statement in Phillipians 2:6 about the form of God corresponds closely with the statement in John 17:5 about the glory which "I had with Thee before the world was." TDNT, 4.751.

35 Biblical scholars argue that morfh\& and ei) kw\&n are used as interchangeable terms in the LXX and in Paul. For example, an investigation of the Old Testament's connection between terms Mlc and twmo in the light of their translation in the LXX as morfh \& lead scholars to believe that "morfh\& in Philippians 2:6 is immediately related to the concept ei) $k w \& n$, since the Semitic root word Mlc can correspond to either of the two Greek words." R. P. Martin, Carmen Christi. Philippians 2.5-11 in Recent Interpretation and in the Setting of Early Christian Worship (Cambridge: Cambridge University Press, 1967), 108. For the discussion of the body/image of Christ in Pauline thought see Jarl Fossum, The Image of the Invisible God (Novum Testamentum et Orbis Antiquus, 30; Göttingen: Vandenhoeck \& Ruprecht, 1995).

36 J. Fossum observes that in some Gnostic circles "'the shining,' 'image,' or 'likeness' of God, after which the body of the earthly man was fashioned appears as a separate entity, even some form of hypostasis." Fossum, The Image of the Invisible God, 16.

${ }^{37}$ Gershom Scholem, On the Mystical Shape of the Godhead (New York: Schocken, 1976), 264.

${ }^{38}$ Cf. S. Brock, "Clothing Metaphors as a Means of Theological Expression in Syriac Tradition," Typus, Symbol, Allegorie bei den östlichen Vätern und ihren Parallelen im Mittelalter (Eichstätter granted for this version to appear in e-Publications@Marquette. Brill Academic Publishers does not grant permission for this article to be further copied/distributed or hosted elsewhere without the express permission from Brill Academic Publishers. 
Beiträge, 4; Regensburg: Friedrich Pustet, 1982), 11-40.

${ }^{39}$ On the anthropomorphite controversy see: Elizabeth A. Clark, The Origenist Controversy: The Cultural Construction of an Early Christian Debate (Princeton: Princeton University Press, 1992); Graham Gould, "The Image of God and the Anthropomorphite Controversy in Fourth Century Monasticism," in Robert J. Daly (ed.), Origeniana Quinta (Bibliotheca Ephemeridum Theologicarum Lovaniensium, CV; Leuven: Leuven University Press, 1992), 549-57.

40 On antianthropomorphic polemics see Elizabeth A. Clark, "New Perspectives on the Origenist Controversy: Human Embodiment and Ascetic Strategies," Church History 59 (1990) 145-62; Lawrence Hennessey, "A Philosophical Issue of Origen's Eschatology: The Three Senses of Incorporeality," in Robert J. Daly (ed.), Origeniana Quinta (Bibliotheca Ephemeridum Theologicarum Lovaniensium, CV; Leuven: Leuven University Press, 1992), 373-80; John A. McGuckin, "The Changing Forms of Jesus," in Lothar Lies (ed.), Origeniana Quarta (Innsbrucker Theologische Studien, Bd. 19; Innsbruck; Wien: TyrolaVerlag, 1987), 215-222; David L. Paulsen, "Early Christian Belief in a Corporeal Deity: Origen and Augustine as Reluctant Witnesses," HTR 83:2 (1990) 105-16; Gedaliahu Stroumsa, "The Incorporeality of God: Context and Implications of Origen's Position," Religion (1983) 345-58. ${ }^{41}$ Similar antropomorphic developments are also noticiable in postbiblical Jewish mysticism, with its gradual elaboration of the Mlc concept. In Jewish tradition $\mathrm{Mlc}$ played an important role in anthropomorphic developments. It was understood not simply as an abstract likeness but had a strong "corporeal meaning." See Alon Goshen Gottstein, "The Body as Image of God in Rabbinic Literature," HTR 87 (1994) 174. See also: Gershom Scholem, On the Mystical Shape of the Godhead (New York: Schocken, 1976), 251-73. Gottstein's research deals with a number of rabbinic texts that reveal this "corporeal" understanding of Mlc. He argues that in some instances it is interchangeable with other Hebrew terms for the designation of "body," like the term twmd. Speaking about these corporeal meanings of $\mathrm{Mlc}$ Gottstein notes that "... Adam's tselem is his luminous body. In other sources, such as the story of Hillel washing his body [Lev.R. 34.3], the tselem referred to the physical body. Tselem can be thus refer to various levels, or aspects, all of which bear a resemblance to the physical body. I would propose that these various levels, or various bodies, reflect one another. The granted for this version to appear in e-Publications@Marquette. Brill Academic Publishers does not grant permission for this article to be further copied/distributed or hosted elsewhere without the express permission from Brill Academic Publishers. 
physical body is a reflection of the body of light. This reflection may translate itself down to the details of circumcision. The kind of graded devolutionary process that we encountered above may be a model for two ways of talking about tselem. The tselem in its original form may be lost, but the dimmer reflection of this form is extant in the physical body, which may still be spoken of as tselem." Alon Goshen Gottstein, "The Body as Image of God in Rabbinic Literature," 188. Rabbinic literature gives a number of references to traditions about the luminosity of the original tselem of Adam. One of them can be found in Lev. R. 20.2. in which "Resh Lakish, in the name of R. Simeon the son of Menasya, said: The apple of Adam's heel outshone the globe of the sun; how much more so the brightness of his face! Nor need you wonder. In the ordinary way if a person makes salvers, one for himself and one for his household, whose will he make more beautiful? Not his own? Similarly, Adam was created for the service of the Holy One, blessed be $\mathrm{He}$, and the globe of the sun for the service of mankind." $\mathrm{H}$. Freedman and M. Simon (tr.), Midrash Rabbah (10 vols.; London: Soncino Press, 1939) 4. 252. Another important passage which can be found in Gen. R. 20.12 tells us that the scroll of Rabbi Meir reads "garments of light" instead of "garments of skin," stressing thus that Adam has not lost completely his luminous quality even after the Fall: "In R. Meir's Torah it was found written, 'Garments of light': this refers to Adam's garments, which were like a torch [shedding radiance], broad at the bottom and narrow at the top." H. Freedman and M. Simon (tr.), Midrash Rabbah (10 vols.; London: Soncino Press, 1939), 1. 171.

42 The Philokalia, 4.377.

${ }^{43}$ An aggadic tradition, which survived in the Syriac environment, explains why Adam and Eve discovered their nakedness only after the Fall. According to the tradition, it happened because after their transgression they lost their original radiance-the "garments of light" which prevented them from seeing their naked "physical" bodies. Luminosity thus served for the prelapsarian humankind as a sort of screen which concealed their original form. Gregory Palamas clearly employs this tradition.

44 "Even though we still bear God's image to a greater degree than the angels, yet as regards the likeness of God we fall far short of them." Philokalia, 4.376.

45 Philokalia, 4.376.

Vigiliae Christianae, Vol. 55 (2001): pg. 281-298. DOI. This article is @ Brill Academic Publishers and permission has been granted for this version to appear in e-Publications@Marquette. Brill Academic Publishers does not grant permission for this article to be further copied/distributed or hosted elsewhere without the express permission from Brill Academic Publishers. 
NOT THE PUBLISHED VERSION; this is the author's final, peer-reviewed manuscript. The published version may be accessed by following the link in the citation at the bottom of the page.

${ }^{46}$ Cf. John S. Romanides, "Notes on the Palamite Controversy and Related Topics," The Greek Orthodox Theological Review 6 (1960-61) 186-205 and The Greek Orthodox Theological Review 9 (1963-64) 225-70.

47 See John S. Romanides, "Notes on the Palamite Controversy and Related Topics," The Greek Orthodox Theological Review 9 (1963-64) 235.

48 On Moses' connection with Kavod theology see: A. Orlov, "Ex 33 on God's Face: A Lesson from the Enochic Tradition," SBLSP 39 (2000), 130-47.

49 Pseudo-Macarius, The Fifty Spiritual Homilies and the Great Letter, 102. H. Dörries et al. Die 50 Geistlichen Homilien des Makarios, 114. 50 The motif of covering with the Glory is also prominent in another Macarian passage which depicts Moses' shining countenance: "For blessed Moses provided us with a certain type through the glory of the Spirit which covered his countenance upon which no one could look with steadfast gaze (II.15.10)." Pseudo-Macarius, The Fifty Spiritual Homilies and the Great Letter, 74.

${ }^{51}$ In Rabbinic literature the traditions about Moses as a luminous conterpart of Adam also can be found. Gottstein stresses that "the luminescent quality of the tselem is the basis for comparison between Moses and Adam in several rabbinical materials." Alon Goshen Gottstein, "The Body as Image of God in Rabbinic Literature," 182. Deut. R. 11.3 attests to such traditions: "Adam said to Moses: 'I am greater than you because I have been created in the image of God.' Whence this? For it is said, 'and God created man in his own image' (Gen. 1,27). Moses replied to him: 'I am far superior to you, for the honor which was given to you has been taken away from you, as it is said: but man (Adam) abideth not in honor, (Ps. XLIX, 13) but as for me, the radiant countenance which God gave me still remains with me.' Whence? For it is said: 'his eye was not dim, nor his natural force abated' (Deut. 34:7)." H. Freedman and M. Simon (tr.), Midrash Rabbah (10 vols.; London: Soncino Press, 1939), 7. 173. Gottstein also gives another midrashic passage from Midrash Tadshe 4 in which Moses is again Adam's luminous counterpart: "In the likeness of the creation of the world the Holy One blessed be he performed miracles for Israel when they came out of Egypt... In the beginning: 'and God created man in his image,' and in the desert: 'and Moshe knew not 
that the skin of his face shone.'" Cf. Adolph Jellinek, Bet ha-Midrash (6 vols.; Jerusalem: Wahrmann, 1967), 3. 168.

52 G. Scholem, Major Trends in Jewish Mysticism ( New York: Schocken, 1961), 79.

53 Pseudo-Macarius, The Fifty Spiritual Homilies and the Great Letter, 37.

${ }^{54}$ G. Scholem, Major Trends in Jewish Mysticism (New York: Schocken, 1961), 79.

55 The original Synoptic accounts of Christ's transfiguration seem influenced by the Kavod paradigm in its classical Exodus' form. Several details of the account serve as important reminders: the vision took place on a mountain, the presence of Moses, a bright cloud that enveloped the visionaries, a voice which came out of the cloud, and the shining face of Christ. On Moses typology in the Synoptic accounts of the Transfiguration see: J. A. McGuckin, The Transfiguration of Christ in Scripture and Tradition (Studies in the Bible and Early Christianity, 9; Lewiston: Edwin Mellen, 1986), 1-19; J. Markus, The Way of the Lord (Louisville: Westminster/John Knox, 1992), 80-93; M. E. Thrall, "Elijah and Moses in Mark's Account of the Transfiguration," NTS 16 (1969-70) 305-17.

56 The verb from the Synoptic account implies that Jesus' body was changed. Cf. J. Behm, TDNT, 4.755-7.

57 Another important testimony to the Lord's Body of Light is PseudoClementine Homily 17:7 which pictures the brilliant radiance of Christ's body in connection with Christ's image: "For He has shape, and He has every limb primarily and solely for beauty's sake, and not for use. For He has not eyes that He may see with them; for He sees on every side, since He is incomparably more brilliant in His body than the visual spirit which is in us, and He is more splendid than everything, so that in comparison with Him the light of the sun may be reckoned as darkness. Nor has He ears that He may hear; for He hears, perceives, moves, energizes, acts on every side. But He has the most beautiful shape on account of man, that the pure in heart may be able to see Him, that they may rejoice because they suffered. For He molded man in His own shape as in the grandest seal, in order that he may be the ruler and lord of all, and that all may be subject to him. Wherefore, judging that $\mathrm{He}$ is the universe, and that man is His image (for $\mathrm{He}$ is Himself invisible, but His image man is visible), the man who wishes to worship Him honours His visible image, which is man." A. Roberts and

Vigiliae Christianae, Vol. 55 (2001): pg. 281-298. DOI. This article is @ Brill Academic Publishers and permission has been granted for this version to appear in e-Publications@Marquette. Brill Academic Publishers does not grant permission for this article to be further copied/distributed or hosted elsewhere without the express permission from Brill Academic Publishers. 
J. Donaldson, eds., The Ante-Nicene Fathers (10 vols.; Grand Rapids: Eerdmans, 1950-51), 8. 319-20. It is important that here Christ's luminosity is placed into the account of Adam's creation after God's image. The phrase "He is incomparably more brilliant in his body than the visual spirit which is in us" deserves particular attention since it can refer to the correspondence between the Lord's luminous "body" and the Adamic tselem.

58 Pseudo-Macarius, The Fifty Spiritual Homilies and the Great Letter, 122-3. H. Dörries et al. Die 50 Geistlichen Homilien des Makarios, 14950.

${ }^{59}$ Origen in Princ. 2.3.7 remarks that the best and purest spirits must have some kind of body, being changed according to their degree of merit into an ethereal condition, and interprets "change" in 1 Cor 15:52 as "shining with light."

60 Pseudo-Macarius, The Fifty Spiritual Homilies and the Great Letter, 122-3. H. Dörries et al. Die 50 Geistlichen Homilien des Makarios, 14950.

${ }^{61}$ It is noteworthy that the homilist applies the imagery of "covering" not only to the physical bodies of these Christians but also to their souls which according to him will be "covered with the beauty of the ineffable glory of the light of Christ." Pseudo-Macarius, The Fifty Spiritual Homilies and the Great Letter, 37.

62 Pseudo-Macarius, The Fifty Spiritual Homilies and the Great Letter, 122-3. H. Dörries et al. Die 50 Geistlichen Homilien des Makarios, 14950.

63 Pseudo-Macarius, The Fifty Spiritual Homilies and the Great Letter, 44.

64 The luminous face and the transformed garments of Christ in the Synoptic accounts of the Transfiguration may stress the role of Christ as a visionary of His own glory. It parallels the shining face of Moses after his visionary experience on Mount Sinai and to the transformation of visionaries' garments in Jewish and Christian apocalypses. 65 Pseudo-Macarius, The Fifty Spiritual Homilies and the Great Letter, 122-3. H. Dörries et al. Die 50 Geistlichen Homilien des Makarios, 14950.

Vigiliae Christianae, Vol. 55 (2001): pg. 281-298. DOI. This article is @ Brill Academic Publishers and permission has been granted for this version to appear in e-Publications@Marquette. Brill Academic Publishers does not grant permission for this article to be further copied/distributed or hosted elsewhere without the express permission from Brill Academic Publishers. 